Notes and Comments

\title{
Intestinal protozoan infections and environment conditions among rural schoolchildren in Western Brazilian Amazon
}

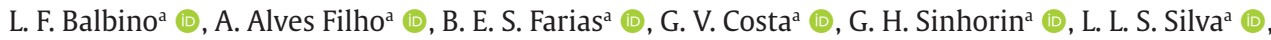

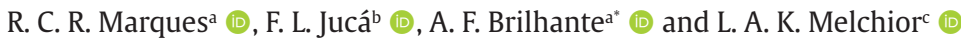 \\ aUniversidade Federal do Acre - UFAC, Cento de Ciências da Saúde e do Desporto, Rio Branco, Rio Branco, AC, Brasil

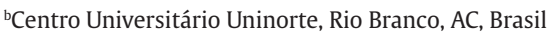 \\ 'Universidade Federal do Acre - UFAC, Centro de Ciências Biológicas e da Natureza, Rio Branco, AC, Brasil
}

To the present day, intestinal parasitic infections represent an important public health problem worldwide, mainly in underdeveloped and developing countries. In this context, Brazil stands out, given the lack of public policies for better coverage of basic sanitation in this country (WHO, 2020a). In addition, it is known that the transmission and growing number of cases are also related to eating habits, as well as cultural and educational behaviours, as parasitic infections are more prevalent in populations of low socioeconomic status (Sandoval et al., 2015; Dessie et al., 2019).

In children, the intestinal parasites can be an important factor bond to comorbidities and deficiencies such as intestinal obstruction, anaemia, undernutrition, growth retardation and mental health damages. In school environment, these conditions could develop poor academic performance, absenteeism and cognitive impairments (Taylor-Robinson et al., 2015). Furthermore, in this setting, children constantly parasitized, without a basic sanitation conditions and access to health services, live in a constant cycle of infection and reinfection between them.

Although the importance of research evaluating the prevalence of these enteroparasites is known, few studies are available in Acre State. In view of the above, the present study aimed to verify the proportion of intestinal parasites in schoolchildren from a rural area in the Western Amazon.

This study was carried out at the Rural State School Ruy Azevedo, and is located in the Praia do Amapá neighbourhood in the rural area of Rio Branco, capital of Acre State, Brazil. A cross-sectional study was conducted between May and June 2019. Each family received a bottle containing Merthiolate-Iodo-Formol (MIF) per child to collect a single stool sample. Parents or legal guardians received verbal and written instructions on how to proceed with the collection. The school has about 300 students enrolled, the sample selection was non-probabilistic and largely determined by voluntary participation. The study included individuals of both sexes aged between five and twelve years.
Stool samples were analysed and coproparasitological tests were performed using formol-ether concentration technique (Blagg et al., 1955), and two slides per sample were analysed. A sample was considered positive when at least one parasite species was detected.

A questionnaire was completed voluntarily by the legal guardian of each participant in order to obtain sociodemographic characteristics and information about use of antiparasitic drugs, and symptoms of gastrointestinal disorders suggestive of enteroparasitosis.

Sociodemographic characteristics and parasitic proportions were analysed by chi-square or Fisher's exact test using the Stata 13.0 program to identify differences in frequencies between participants at the $5 \%$ level of significance.

The study was conducted after approval of the project by the Ethics and Research Committee from Federal University of Acre, under number ID CAAE 02873118.2.0000.5010.

A total of 58 children participated in the survey, of which of them only 47 delivered the stool sample. Of these, $57.45 \%$ were male, while $42.55 \%$ were female. The children examined were aged between five and twelve years, with an average of approximately eight years of age and two years of standard deviation.

The infection by enteroparasites was found in 43 children (91.48\%). Protozoan infections were more frequent than helminth infections; these results are shown in Table 1. Monoparasitism was identified in $25.53 \%$ of children, while more than the half (65.96\%) had polyparasitism with up to six parasite species.

The proportions observed between sociodemographic data, clinical aspects and positive diagnosis did not show significant statistical differences at the 5\% level, except for income, this result is detailed in the Table 2. It is likely that this is due to the level of exposure to pathogens, various forms of infection, and the homogeneity of the samples studied. Other information according to the collected data were; the per capita monthly income was calculated as $\mathrm{R} \$ 191.41$ reais, corresponding to $\$ 1.25$ dolar per capita per day. Only $15.52 \%$ of households had running water, while

*e-mail: andreia.brilhante@ufac.br

Received: January 13, 2021 - Accepted: March 17, 2021

This is an Open Access article distributed under the terms of the Creative Commons Attribution License, which permits unrestricted use, distribution, and reproduction in any medium, provided the original work is properly cited. 
Table 1. Distribution of intestinal parasites, polyparasitism and monoparasitism in schoolchildren from Rural School Ruy Azevedo, Acre State, Brazilian Western Amazon, 2019 ( $\mathrm{n}=47)$.

\begin{tabular}{|c|c|c|c|c|c|c|}
\hline Parasites & Male (n) & $\%$ & Female (n) & $\%$ & Total (n) & $\%$ \\
\hline Blastocystis sp. & 12 & 44.44 & 5 & 25.00 & 17 & 36.17 \\
\hline Endolimax nana & 21 & 77.77 & 11 & 55.00 & 33 & 70.21 \\
\hline Entamoeba coli & 5 & 18.51 & 5 & 25.00 & 10 & 21.27 \\
\hline Entamoeba histolytica/dispar & 8 & 29.62 & 6 & 30.00 & 14 & 29.78 \\
\hline Giardia duodenalis & 8 & 29.62 & 9 & 45.00 & 17 & 36.17 \\
\hline Iodamoeba sp. & 11 & 40.74 & 6 & 30.00 & 17 & 36.17 \\
\hline Hookworm & - & - & 1 & 5.00 & 1 & 2.12 \\
\hline Ascaris lumbricoides & - & - & 1 & 5.00 & 1 & 2.12 \\
\hline Taenia sp. & 1 & 3.70 & - & - & 1 & 2.12 \\
\hline Polyparasitism & 19 & 70.37 & 12 & 60.00 & 31 & 65.96 \\
\hline Monoparasitism & 5 & 18.51 & 7 & 35.00 & 12 & 25.53 \\
\hline Negative cases & 4 & 14.81 & - & - & 4 & 8.51 \\
\hline
\end{tabular}

$84.48 \%$ used water from simple wells. About $20.69 \%$ of the families reported cultivating a vegetable garden for their own consumption.

Regarding the signs and symptoms caused by infections with enteroparasites, $18.97 \%$ of children were symptomatic, of which $17.24 \%$ and $13.79 \%$ reported to have diarrhoea and emesis, respectively. It was identified that $27.58 \%$ never had a parasitological examination of their faeces, $44.82 \%$ had an examination more than a year ago, $20.69 \%$ less than a year ago, and $6.89 \%$ did not respond. Of these children, $82.76 \%$ were dewormed, either within the last six months (31.25\%), the last year (22.91\%), or the last five years (25\%).

In our study, we verified the high proportion of intestinal protozoa among the enteroparasitic agents identified. These results corroborate with findings made in some regions of Brazil with high prevalences reported by Oliveira et al. (2003) (65.4\%) and Gurgel et al.(2005) (51.5\%), and even globally by Gutierrez-Jimenez et al.(2013)(63.8\%) and Dessie et al. (2019) (29.9\%). In Acre State, particularly in Acrelândia and Assis Brasil municipalities, some studies have found high prevalence of intestinal parasites in children, $32.4 \%$ and $31.7 \%-53.4 \%$, respectively, the most infections were due to protozoa, such as Giardia duodenalis and Entamoeba coli (Souza et al., 2007; Muniz et al., 2007). The authors of those studies agree that most of these infections occur because these populations live in precarious conditions of basic sanitation.

The highest prevalence being observed in tropical countries is due to the fact that they have the environmental conditions of tropical areas, temperature, and humidity, which are predisposing factors for renewing the parasites' life cycles (Biasi et al., 2010). In the state of Acre, as part of the Amazon biome, the climatic and environmental conditions are similar to those presented above. In addition, the low conditions of basic sanitation that the studied population is exposed.

The risk factors for the development of enteroparasitosis include contact with residues of different natures and water contaminated with human faeces, inadequate housing conditions, poor hygiene practices, low education, and family income. Continued exposure to these factors is important for maximizing the parasitic burden and, therefore, the development of intestinal parasites. It is worth noting that the very same conditions are predisposing factors of polyparasitism (Dessie et al., 2019; Sandoval et al., 2015).

Although enteroparasitosis affects individuals of all ages, the most vulnerable group is the one with the lowest age, coupled with the fact that children have greater contact with the soil through recreational activities. It is also noteworthy that the finding of a case of Taenia sp., such as Taenia solium, may precede cases of cysticercosis and causing co-infections (Madinga et al., 2017).

In Brazil, the scarcity of statistical data that account for the real prevalence of these parasites makes it difficult to understand the current situation in the country, and these data are only available partially and in specific settings. The World Health Organization, in its most recent report about helminths transmitted by the soil from 2018 , reported that in Brazil, the number of children of preschool and school age who require preventive chemotherapy was more than nine million. Of these, about $80 \%$ had preventive chemotherapy coverage. However, this coverage was only applied to schoolchildren aged five to fifteen years (WHO, 2020b). In our study, the children were between five and twelve years of age; yet, we still revealed a high proportion of positive cases due to low sanitary conditions to which these children are exposed, and difficulties in accessing health services in the region according reports from the school management.

Our findings point to a continued faecal-oral transmission to which these populations are exposed, reflecting the need to expand basic sanitation services, and implement health and environmental education programs. However, some limitations in this study are: 1) the low n because of low adherence of the chlidren's parents in participate of this research, that could might describe better the prevalence of the infections at the 
Table 2. Distribuition of sociodemographic data, clinical aspects and positive diagnosis, analysed by Pearson's chi-square at at the $5 \%$ level of significance, Rural School Ruy Azevedo, Acre State, Brazilian Western Amazon, 2019.

\begin{tabular}{|c|c|c|c|}
\hline Variables & Positive case (n) & Negative case (n) & p-value \\
\hline \multicolumn{4}{|l|}{ Sociodemographics } \\
\hline \multicolumn{4}{|l|}{ Sex } \\
\hline Female & 18 & 1 & 0.305 \\
\hline Male & 23 & 4 & \\
\hline \multicolumn{4}{|l|}{ Age } \\
\hline 5 & 3 & 1 & 0.779 \\
\hline 6 & 9 & 1 & \\
\hline 7 & 5 & 1 & \\
\hline 8 & 5 & 0 & \\
\hline 9 & 2 & 1 & \\
\hline 10 & 7 & 0 & \\
\hline 11 & 6 & 1 & \\
\hline 12 & 1 & 0 & \\
\hline \multicolumn{4}{|l|}{ Income (RS) } \\
\hline $39-99$ & 4 & 0 & 0.059 \\
\hline $100-500$ & 10 & 2 & \\
\hline $501-1000$ & 14 & 1 & \\
\hline $1001-2000$ & 12 & 0 & \\
\hline$>2001$ & 1 & 2 & \\
\hline \multicolumn{4}{|l|}{ Parents' school level } \\
\hline Complete / incomplete elementary school & 9 & 3 & 0.286 \\
\hline Complete / incomplete high school & 23 & 2 & \\
\hline Complete/incomplete higher education & 8 & 0 & \\
\hline Illiterate & 1 & 0 & \\
\hline \multicolumn{4}{|l|}{ Type of drinking water } \\
\hline From the tap & 19 & 1 & 0.569 \\
\hline Boiled & 3 & 1 & \\
\hline Filtered & 9 & 2 & \\
\hline Mineral water & 6 & 1 & \\
\hline \multicolumn{4}{|l|}{ House structure } \\
\hline Wooden house & 10 & 2 & 0.613 \\
\hline Brick's house & 24 & 3 & \\
\hline Mixed (bricks and wooden) & 5 & 0 & \\
\hline \multicolumn{4}{|l|}{ Bathroom indoors } \\
\hline Yes & 24 & 2 & 0.765 \\
\hline No & 17 & 2 & \\
\hline \multicolumn{4}{|l|}{ Own vegetable garden at home } \\
\hline Yes & 9 & 1 & 0.899 \\
\hline No & 31 & 4 & \\
\hline \multicolumn{4}{|l|}{ Clinical aspects } \\
\hline \multicolumn{4}{|l|}{ Diarrhea } \\
\hline Yes & 4 & 1 & 0.534 \\
\hline No & 34 & 4 & \\
\hline
\end{tabular}


Table 2. Continued...

\begin{tabular}{|c|c|c|c|c|}
\hline & Variables & Positive case (n) & Negative case (n) & p-value \\
\hline \multicolumn{5}{|c|}{ Nausea } \\
\hline Yes & & 6 & 1 & 0.771 \\
\hline No & & 34 & 4 & \\
\hline \multicolumn{5}{|c|}{ Emesis } \\
\hline Yes & & 5 & 1 & 0.678 \\
\hline No & & 33 & 4 & \\
\hline \multicolumn{5}{|c|}{ Dewormed* } \\
\hline Yes & & 36 & 5 & 0.459 \\
\hline No & & 4 & 0 & \\
\hline
\end{tabular}

locality; and 2) due to lack better conditions of laboratory equipments and supplies to perform other parasitological tests, as for oportunist parasites.

\section{Acknowledgements}

The authors wish thank to the teachers and staff of the Rural School Ruy Azevedo for their support to carry out this research. The authors also thank to Conselho Nacional de Desenvolvimento de Científico e Tecnológico for the scholarship granted to Balbino, L.F.

\section{References}

BIASI, L.A., TACCA, J.A., NAVARINI, M., BELUSSO, R., NARDINO, A. SANTOLIN, J.C., BERNARDON, V. and JASKULSKI, M.R., 2010. Prevalência de enteroparasitoses em crianças de entidade assistencial de Erechim/RS. Perspectiva, vol. 34, no. 125, pp. 173-179.

BLAGG, W., SCHOLOEGEL, E.L., MANSOUR, N.S. and KHALAF, G.L., 1955. A new concentration technique for the demonstration of protozoa and helminth eggs in feces. The American Journal of Tropical Medicine and Hygiene, vol. 4, no. 1, pp. 23-28. http:// dx.doi.org/10.4269/ajtmh.1955.4.23.

DESSIE, A., GEBREHIWOT, T.G., KIROS, B., WAMI, S.D. and CHERCOS, D.H., 2019. Intestinal parasitic infections and determinant factors among school-age children in Ethiopia: a cross-sectional study. BMC Research Notes, vol. 12, no. 1, pp. 777. http://dx.doi. org/10.1186/s13104-019-4759-1. PMid:31779671.

GURGEL, R.Q., CARDOSO, G.S., SILVA, A.M., SANTOS, L.N. and OLIVEIRA, R.C.V., 2005. Creche: ambiente expositor ou protetor nas infestações por parasitos intestinais em Aracaju, SE. Revista da Sociedade Brasileira de Medicina Tropical, vol. 38, no. 3, pp. 267-269. http://dx.doi.org/10.1590/S0037-86822005000300014. PMid:15895183.

GUTIERREZ-JIMENEZ, J., TORRES-SANCHEZ, M.G.C., FAJARDOMARTINEZ, L.P., SCHLIE-GUZMAN, M.A., LUNA-CAZARES, L.M., GONZALEZ-ESQUINCA, A.R., GUERRERO-FUENTES, S. and VIDAL, J.E., 2013. Malnutrition and the presence of intestinal parasites in children from the poorest municipalities of Mexico. Journal of Infection in Developing Countries, vol. 7, no. 10, pp. 741-747. http://dx.doi.org/10.3855/jidc.2990. PMid:24129627.

MADINGA, J., POLMAN, K., KANOBANA, K., VAN LIESHOUT, L., BRIENEN, E., PRAET, N., KABWE, C., GABRIËL, S., DORNY, P.,
LUTUMBA, P. and SPEYBROECK, N., 2017. Epidemiology of polyparasitism with Taenia solium, schistosomes and soiltransmitted helminths in the co-endemic village of Malanga, Democratic Republic of Congo. Acta Tropica, vol. 171, pp. 186-193. http://dx.doi.org/10.1016/j.actatropica.2017.03.019. PMid:28336269.

MUNIZ, P.T., CASTRO, T.G., ARAÚJO, T.S., NUNES, N.B., SILVA-NUNES, M., HOFFMANN, E.H.E., FERREIRA, M.U. and CARDOSO, M.A., 2007. Child health and nutrition in the Western Brazilian Amazon: population-based surveys in two counties in Acre State. Cadernos de Saude Publica, vol. 23, no. 6, pp. 1283-1293. http://dx.doi. org/10.1590/S0102-311X2007000600004. PMid:17546320.

OLIVEIRA, M.C., SILVA, C.V. and COSTA-CRUZ, J.M., 2003. Intestinal parasites and commensals among individuals from a landless camping in the rural area of Uberlândia, Minas Gerais, Brazil. Revista do Instituto de Medicina Tropical de Sao Paulo, vol. 45, no. 3, pp. 173-176. http://dx.doi.org/10.1590/S003646652003000300011. PMid:12870069.

SANDOVAL, N.R., RÍOS, N., MENA, A., FERNÁNDEZ, R., PEREA, M., MANZÁNO-ROMAN, R., SANTA-QUITERIA, J.A.R., HERNÁNDEZGONZALEZ, A. and SILES-LUCAS, M., 2015. A survey of intestinal parasites including associated risk factors in humans in Panama. Acta Tropica, vol. 147, pp. 54-63. http://dx.doi.org/10.1016/j. actatropica.2015.03.024. PMid:25823566.

SOUZA, E.A., DA SILVA-NUNES, M., MALAFRONTE, R.S., MUNIZ, P.T., CARDOSO, M.A. and FERREIRA, M.U., 2007. Prevalence and spatial distribution of intestinal parasitic infections in a rural Amazonian settlement, Acre State, Brazil. Cadernos de Saude Publica, vol. 23, no. 2, pp. 427-434. http://dx.doi.org/10.1590/ S0102-311X2007000200019. PMid:17221092.

TAYLOR-ROBINSON, D.C., MAAYAN, N., SOARES-WEISER, K., DONEGAN, S. and GARNER, P., 2015. Deworming drugs for soiltransmitted intestinal worms in children: effects on nutritional indicators, haemoglobin, and school performance. The Cochrane Database of Systematic Reviews, no. 7, pp. CD000371. http:// dx.doi.org/10.1002/14651858.CD000371.pub6. PMid:26202783.

WORLD HEALTH ORGANIZATION - WHO, 2020a [viewed 20 April 2020]. Soil-transmitted helminth infections [online]. Geneva: WHO. Available from: https://www.who.int/gho/neglected diseases/soil_transmitted_helminthiases/en/

WORLD HEALTH ORGANIZATION - WHO, 2020b [viewed 20 April 2020]. Soil-transmitted helminth infections. Number of children (Pre-SAC and SAC) requiring preventive chemotherapy for soil helminth infections. [online]. Geneva: WHO. Available from: https://apps.who.int/neglected_diseases/ntddata/sth/sth. html*in the last six months. 